\title{
TPROXY dan FILTERING SEBAGAI METODE OPTIMASI PEMAKAIAN BANDWIDTH INTERNET
}

\author{
Sutiyo \\ Jurusan Teknik Elektro, Fakultas Teknik, Universitas Widya Dharma Klaten \\ Jl. KH Dewantara, Klaten Utara, Klaten \\ email: tio@unwidha.ac.id
}

\begin{abstract}
Until now the use of the internet disuatu agencies viewed from the initial planning, use and care, even long-term planning is still not optimal. The main factor lies in the existing human resources, especially in IT personnel and policy makers who do not understand or do not even know at all how your use of the Internet well, optimal, efficient, particularly associated with the consumption of Internet bandwidth. Internet bandwidth capacity greatly affect the speed of web access or other Internet applications. So we need a plan and maintance necessary to obtain good Internet bandwidth consumption efficiency and guaranteed QoS, such as by utilizing Tproxy and filtering methods. TProxy is a development of which has been patched Squid, a proxy to be able to pass traffic without NAT (Network Access Translation). Fitering a firewall system which is used for filtering data packets that do not want filtered dikendaki or akhirmya able to minimize traffic on bandwidth usage. Tproxy and filtering runs on the Linux platform. Linux distributions are often used to Tproxy is a variant Debian, Centos and then to use Mikrotik Filtering. At the end of each request or query from the client or the response of the proxy server does not have meaningful constraints, the bandwidth between the client and the proxy server does not happen limitation, bandwidth capable of running close to capacity including $10 \mathrm{Mbps}$ Ethernet, 100 Mbps, and even a GPS (full speed).
\end{abstract}

\section{Keywords : Tproxy, Filtering, QoS, Bandwidth}

Sampai saat ini pemanfaatan internet disuatu instansi dilihat dari perencanaan awal, penggunaan dan perawatan, bahkan perencanaan jangka panjang masih sangat belum optimal. Faktor utamanya terletak pada sumber daya manusia yang ada, khususnya pada tenaga IT dan pembuat kebijakan yang belum memahami atau bahkan tidak tahu sama sekali bagaiamana memanfaatkan internet dengan baik, optimal, efisien khususnya terkait dengan konsumsi bandwidth internet. Kapasitas bandwidth internet sangat berpengaruh terhadap kecepatan akses web atau aplikasi internet lainnya. Sehingga perlu diperlukan rencana dan maintance yang bagus untuk mendapatkan efisiensi konsumsi bandwidth internet dan QoS yang terjamin, diantaranya dengan memanfaatkan metode Tproxy dan Filtering. TProxy merupakan pengembangan dari Squid yang telah dipatch, untuk dapat melalukan trafik proxy tanpa NAT (Network Access Translation). Fitering merupakan sistem firewall yang dimanfaatkan untuk penyaringan paket-paket data yang tidak dikendaki atau ingin disaring yang pada akhirmya mampu meminimalkan traffik penggunaan bandwidth. Tproxy dan Filtering berjalan pada platform Linux. Distribusi Linux yang sering digunakan untuk Tproxy adalah varian Debian, Centos kemudian untuk Filtering menggunakan Mikrotik. Pada akhirnya setiap permintaan atau query dari klien atau respon dari proxy server tidak mempunyai hambatan berarti, bandwidth antara klien dengan proxy server tidak terjadi limitasi, bandwidth yang berjalan mampu mendekati kemampuan ethernet diantaranya $10 \mathrm{Mbps}, 100 \mathrm{Mbps}$, bahkan 1 Gps (full speed).

Kata Kunci : Tproxy, Filtering, QoS, Bandwidth

\section{PENDAHULUAN}

\subsection{Latar Belakang}

Internet dikatakan sebagai sumber daya informasi, sebutan tersebut bukan suatu hal yang biasa. Dikatakan demikian karena internet merupakan penyedia informasi terbesar dan terluas di dunia. Selain sumber daya informasi ada juga yang menyebut internet sebagai perpustakaan 
dunia, karena informasi apapun dapat ditemukan didalamnya dari sumber yang berbeda serta dengan bahasa yang beragam.

Kita ketahui bersama bahwa internet telah banyak memberikan keuntungan-keuntungan dan kemudahan, pemakaian internet di berbagai instansi. Instansi tersebut diantaranya instansi pendidikan, intansi pemerintahan. Penggunaan internet hendaknya diatur sedemikian rupa sehingga aktifitas online yang dilakukan benar-benar kegiatan yang sesuai dengan aktifitas institusi, yang selalu diawasi dengan baik.

Didalam dunia pendidikan, para civitas akademika seharusnya mengetahui bahwa selain dampak positif yang diberikan terdapat juga dampak negatif yang bisa diakibatkan oleh internet, misalkan saja pengaksesan situs-situs berbau kekerasan, pornografi yang mampu menghambat pembelajaran siswa.

Sampai saat ini pemanfaatan internet diberbagai institusi masih kurang optimal dilihat dari perencanaan awal, penggunaan dan perawatan, bahkan perencanaan jangka panjang. Faktor utamanya terletak pada sumber daya manusia yang ada di institusi tersebut terutama pada tenaga IT dan pembuat kebijakan yang belum memahami atau bahkan tidak tahu sama sekali bagaiamana memanfaatkan akses internet dengan baik, optimal, sehingga dapat memberikan nilai efisiensi terkait dengan konsumsi bandwidth internet.

\subsection{Perumusan Masalah}

Dengan kurangnya pemahaman dari sumber daya manusia, terutama tenaga IT dari suatu instansi terhadap optimasi pemanfaatan teknologi internet dapat dimanfaatkan oleh penyedia jasa internet. Tanpa melihat kualitas ataupun fungsionalnya instansi kemudian tanpa berpikir panjang menerima tawaran dari penyedia jasa internet atau sering disebut ISP (Internet Service Provider).

Sebelum kita berhubungan dengan ISP seharusnya kita sudah membuat daftar kebutuhan bandwidth sesuai dengan fungsional, berkonsultasi ataupun mencari informasi diberbagai media, bagaimana caranya menghitung konsumsi bandwidth dan bagaimana menghemat pemakaian bandwidth-nya.

Umumnya konsumsi bandwidth menjadi tinggi disaat kita mengakses sebuah web yang banyak mengandung gambar, animasi, video, suara, atau aplikasi multimedia lain. Membuka web-web pornografi juga banyak "menyedot" (red. menghabiskan) bandwidth.

Sehingga jelas perlu diadakan filtering terhadap-hadap website negatif dan bahkan website bernuansa 'social networking' semacam friendster, facebook, sehingga akan tercipta "Internet Sehat" seperti yang telah digalakkan oleh pemerintah dan berbagai lembaga ICT di Indonesia. Selain dengan filtering, tidak kalah pentingnya dengan penggunaaan teknologi proxy terbaru yaitu TProxy. TProxy merupakan proxy yang dapat bekerja lebih optimal tanpa NAT (Network Access Translation).

\section{PEMBAHASAN}

\subsection{Bandwidth}

Di dalam jaringan komputer, bandwidth sering digunakan sebagai suatu sinonim untuk data transfer rate yaitu jumlah data yang dapat dibawa dari sebuah titik ke titik lain dalam jangka waktu tertentu (pada umumnya dalam detik). Jenis bandwidth ini biasanya diukur dalam bps (bits per second) atau dalam Bps (bytes per second).

Alokasi bandwidth adalah sebuah proses menentukan jatah bandwidth kepada pemakai dan aplikasi dalam sebuah jaringan. Termasuk didalamnya menentukan prioritas terhadap berbagai jenis aliran data berdasarkan seberapa penting atau krusial dan delay-sensitive aliran data tersebut. Hal ini memungkinkan penggunaan bandwidth yang tersedia secara efisien dan apabila sewaktu-waktu jaringan menjadi lambat, aliran data yang memiliki prioritas yang lebih rendah dapat dihentikan, sehingga aplikasi yang penting dapat tetap berjalan dengan lancar.

Besarnya kapasitas bandwidth akan berdampak pada kecepatan transmisi. Kecepatan transmisi tersebut sangat dibutuhkan untuk aplikasi komputer yang memerlukan jaringan terutama aplikasi real-time, seperti video conference. Bandwidth internet yang disediakan oleh ISP umumnya mempunyai QoS (Quality Of Service) atau nilai kualitas dari layanan yang diberikan, ISP sering meng-klaim mampu memberikan QoS dan SLA (Service Level Agreement) sebesar $99 \%$, tapi hal ini perlu dipertanyakan.

Pada dasarnya bandwidth merepresantasikan kapasitas dari koneksi, semakin tinggi kapasitas, maka umumyna akan diikuti oleh kinerja yang lebih baik, meskipun kinerja keseluruhan juga tergantung kepada faktor-faktor lain, seperti latency, jitter. 


\subsection{Manajemen Bandwidth}

Mengatur bandwidth merupakan metode untuk mengalokasikan maksimum atau minimum bandwidth untuk setiap user atau komputer. Hal tersebut menjadi permasalahan bagi banyak operator atau teknisi untuk menjaga agar penggunaan bandwidth dapat maksimal untuk keperluan yang baik dengan keterbatasan yang ada.

Ada dua (2) teknik manajemen bandwidth yang banyak digunakan di lapangan, yaitu, HTB dan $C B Q$. $C B Q$ merupakan teknik yang paling lama, $H T B$ lebih baru dari $C B Q$. Beberapa laporan atau literatur menyebutkan bahwa $H T B$ lebih baik dari $C B Q$.

Salah satu sistem operasi yang mempunyai kemampuan manajemen bandwidth dengan berbagai fitur dan teknik pembagian seperti yang disebutkan diatas adalah Mikrotik RouterOS, sebuah operating system yang berjalan di platform Linux tetapi berbayar, yang memang dikhususkan untuk pemakaian dibidang jaringan.

Dengan membagi bandwidth sesuai kebutuhan ke tiap-tiap user, diharapkan dapat mengoptimalkan penggunaan jaringan sesuai porsi dan kebutuhan masing- masing user. Dari hasil percobaan yang diperoleh, kualitas video streaming(unicast) cukup baik. Hal ini dapat dilihat dari nilai delay yang terjadi masih dalam kategori yang diperbolehkan untuk komunikasi video streaming (karena delay yang dihasilkan masih dibawah $150 \mathrm{~ms}$ ), packet loss masih sangat kecil $(<1 \%)$ sehingga video streaming (unicast)dapat diterapkan.

Sedangkan untuk kondisi tiga client (multicast), kualitas video streaming tidak cukup baik. $\mathrm{Hal}$ ini dapat dilihat dari nilai jitter( $>1 \mathrm{~ms})$, dan paket loss $(>1 \%)$ yang tidak termasuk dalam kategori yang diperbolehkan untuk komunikasi video streaming, sehingga video streaming (multicast) tidak dapat diterapkan. Untuk aplikasi data, mikrotik mampu menstabilkan bandwidth pada jaringan dengan baik.

\subsection{QoS (Quality Of Service)}

Lebih jauh mengenai QoS adalah kemampuan untuk menentukan prioritas yang berbedabeda pada berbagai aplikasi, pengguna, atau aliran data guna menjamin tingkat kinerja tertentu ke aliran data network yang telah memenuhi kriteria-kriteria tertentu yang dibuat oleh manager network. Kriteria tersebut termasuk:

a. Availability, yaitu persentase hidupnya sistem atau layanan yang diberikan. Idealnya, availability harus mencapai $100 \%$ atau setidaknya 99,9999\% (ada 6 buah angka sembilan), yang menunjukkan tingkat kerusakan sebesar 2,6 detik per bulan.

b. Bandwidth Usages, yaitu masing-masing user akan diberikan bandwidth sesuai kebutuhan mereka. Selain berdasarkan user, pemakaian bandwidth juga dapat dibagi berdasarkan jenis traffic atau jenis protocol. Misalnya, untuk trafik HTTP dialokasikan bandwidth sebesar $40 \%$, untuk voice $25 \%$, sisanya untuk ftp dan lain-lain. Yang terakhir ini sering disebut dengan "traffic shaper".

c. Throughput, yaitu kecepatan (rate) transfer data efektif yang diukur dalam bps (bit per second)..

d. Latency, adalah waktu yang dibutuhkan data untuk menempuh jarak dari asal ke tujuan. Tundaan (delay) ini dapat dipengaruhi oleh jarak (misalnya akibat penggunaan wireless $L A M$ ), kepadatan link yang memperpanjang antrian, atau waktu olah yang lama (misalnya proses baca-tulis pada sebuah proxy,server).

e. Packet Loss, yaitu jumlah paket yang hilang. Umumnya perangkat network memiliki buffer untuk menampung data yang diterima. Jika terjadi kepadatan trafik yang cukup lama, buffer akan penuh, dan data baru tidak dapat diterima. Paket yang hilang ini harus dire-transmisi, yang akan membutuhkan waktu tambahan.

\subsection{TProxy (Transparent Proxy)}

Makna "transparent proxy" sering diartikan salah sebagai "intercepting proxy" karena tidak diperlukan konfigurasi proxy di klien dan klien tidak bisa mendeteksi apakah requestnya dilewatkan ke proxy dulu atau tidak. Transparent proxy adalah fasilitas dimana router/proxy akan melakukan forward port. Setiap proxy server mempunyai port sendiri yang dapat diatur oleh kita sendiri, contohnya 3128 , tentunya setiap client yang terhubung ke proxy server harus melakukan konfigurasi port di mesin client itu sendiri. Akan terasa repot jika client yang terhubung itu banyak sekali, maka dari itu, Transparent akan melakukannya secara otomatis, dimana port 80(port standar WWW akan di-redirect secara otomatis oleh transparent proxy tadi. 
Salah satu fungsi proxy adalah untuk menyimpan cache. Apabila sebuah LAN menggunakan proxy untuk berhubungan dengan Internet, maka ketika user mengakses sebuah url web site yang dilakukan oleh browser adalah mengambil request tersebut di proxy server. Sedangkan jika data belum terdapat di proxy server maka proxy mengambilkan langsung dari web server. Kemudian request tersebut disimpan di cache proxy. Selanjutnya jika ada client yang melakukan request ke url yang sama, akan diambilkan dari cache tersebut. Ini akan membuat akses ke Internet lebih cepat. Proxy yang mempunyai kemampuan transparent atau intercepting dan sistem cache yang handal adalah SQUID.

Kemampuan Squid perlu di eksplore lebih jauh, jika hanya menggunakan metode transparent squid proxy biasa, kita hanya mendapatkan keuntungan dalam menghemat bandwidth sedangkan untuk pengaturan bandwidth ke masing-masing klien tidak bisa kita lakukan karena semua telah di NAT (Network Access Translation) oleh squid sehingga IP yang muncul di gateway adalah IP squid itu sendiri. Ini tentunya menjadi kekurangan sendiri dalam hal memajemen bandwidth , filtering dan monitoring penggunaan internet. Sehingga perlu dibuat sebuah kernel linux baru yang support TPROXY.

Dengan TPROXY kemampuan cache dari proxy server dapat lebih optimal diakses oleh klien-klien. Dan pengaturan bandwidth setiap klien komputer dapat diatur dan dimonitor lewat perangkat bandwidth manager, misalnya Mikrotik. Tproxy dapat di unduh di http://balabit.com ,kemudian di -pacth kan kedalam sebuah Kernel Linux yang dapat diunduh di http://www.kernel.org

\section{$2.5 \quad$ Filtering}

Filtering tidak jauh berbeda dengan firewall, filtering merupakan salah satu sub dalam dunia kemaanan jaringan. Filtering lebih khusus pada penyaringan paket-paket data yang tidak dikendaki atau ingin disaring. Setelah disaring, apakah data akan di blok atau diteruskan.

Kemampuan filtering paket data salah satunya berada pada layer 7 yaitu di application layer. Filtering dengan Layer 7 juga sudah ada dalam paket software router bernama Mikrotik.

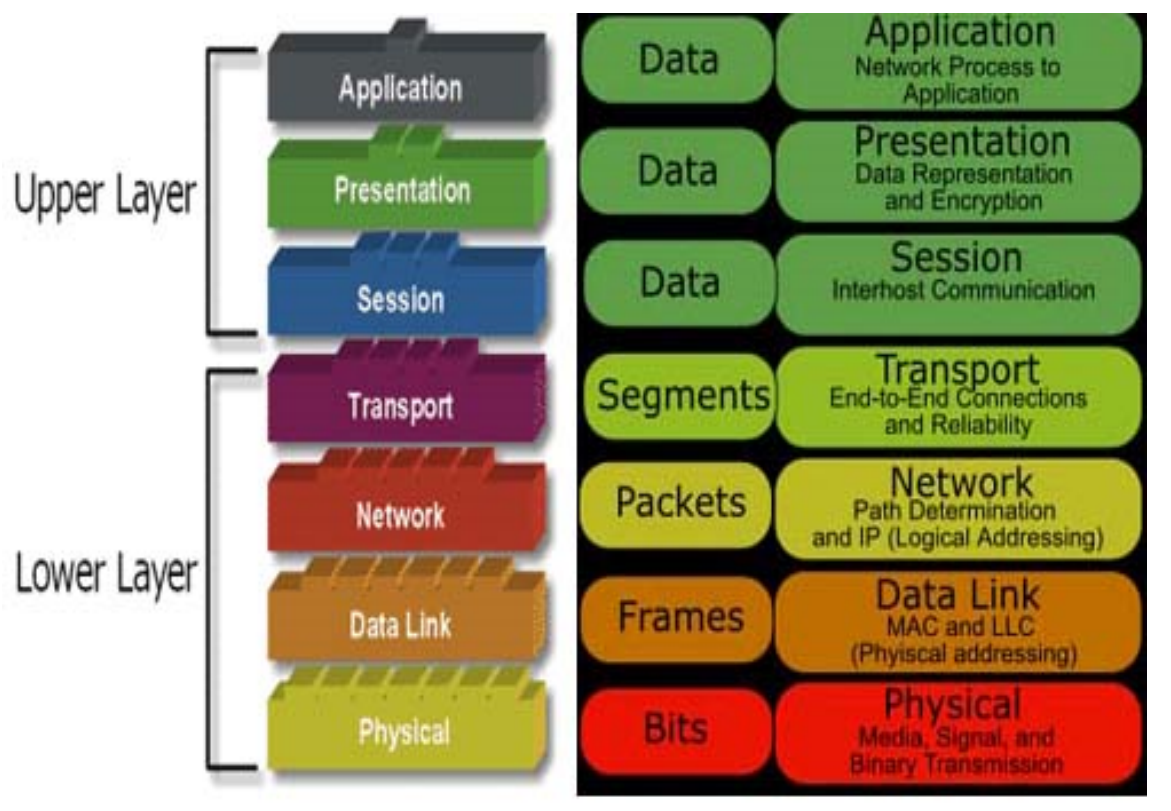

Gambar 1. Lapisan OSI - Upper Layer dan Lower Layer

Layer 7 yaitu firewall yang mampu membaca ip tidak hanya pada headernya tapi sampai ketempat yang lebih dalam, dengan demikian firewall akan tahu aplikasi apa saja yang di bawa oleh suatu IP dalam suatu trafik data.

Layer 7 merupakan protokol dengan metode mencari pola dalam suatu koneksi jaringan. Layer 7 dapat mengklasifikasikan paket sebagai Kazaa, HTTP, Jabber, Citrix, Bittorrent, FTP, Gnucleus, eDonkey2000, dll. Dari klasifikasi paket inilah kita dapat melakukan tindakantindakan yang inginkan sesuai dengan kebutuhan. 


\subsection{Desain LAN}

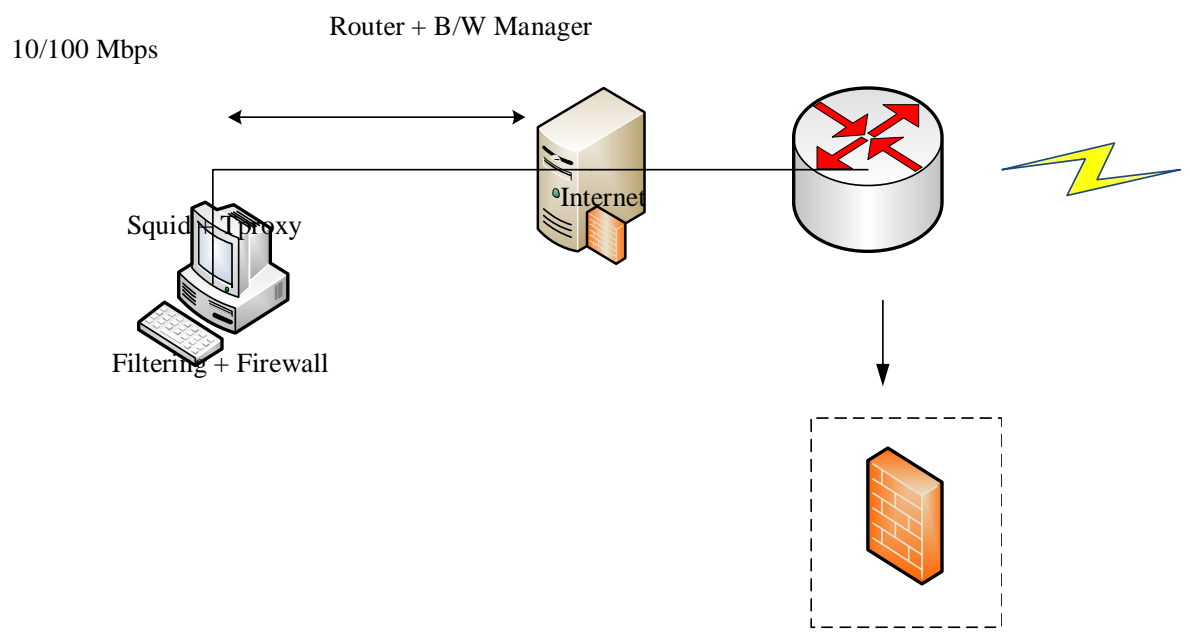

Gambar 2. Desain LAN dengan Tproxy

\subsection{Instalasi TProxy}

Contoh instalasi Tproxy dilakukan pada Ubuntu Server 10.04 dengan Squid-3.17 (sudah dipatch dengan Tproxy), berikut cara instalasinya :

a. Instalasi library dan download source squid

root@proxy: \# aptitude install build-essential libcap2-dev libltdl-dev ebtables bridge-utils

root@proxy: \#cd/usr/src

root@proxy:/usr/src\# apt-get build-dep squid3

root@proxy:/usr/src\#_ wget http://www.squid-cache.org/Versions/v3/3.1/squid-

3.1.7.tar.bz2

root@proxy:/usr/src\#tarxvfj squid-3.1.7.tar.bz2

root@proxy:/usr/src\# cd squid-3.1.7

b. Compilasi squid

root@proxy:/usr/src/squid-3.1.7\# ./configure --build=x86_64-linux-gnu --prefix=/usr -includedir=/usr/include $\quad$--infodir=/usr/share/info $\quad$--localstatedir=/var $\quad$-libexecdir=/usr/lib/squid3 --disable-maintainer-mode --disable-dependency-tracking -disable-silent-rules --srcdir=. --datadir=/usr/share/squid3 --sysconfdir=/etc/squid3 -mandir=/usr/share/man --with-cppunit-basedir=/usr --enable-inline --enable-async-io=8 -enable-storeio=ufs, aufs, diskd --enable-removal-policies=Iru, heap --enable-delay-pools -enable-cache-digests --enable-underscores --enable-icap-client --enable-follow-xforwarded-for --enable-auth=basic,digest,ntIm, negotiate --enable-basic-authhelpers=LDAP,MSNT,NCSA,PAM,SASL,SMB,YP, getpwnam, multi-domain-NTLM --enabledigest-auth-helpers=Idap,password --enable-negotiate-auth-helpers=squid_kerb_auth -enable-external-acl-helpers=ip_user,Idap_group,session,unix_group,wbinfo_group - -enable-arp-acl --enable-snmp --with-filedescriptors $=65536$--with-large-files --with-defaultuser=proxy --enable-epoll --enable-linux-netfilter

c. Instalasi squid

root@proxy:/usr/src/squid-3.1.7\# make \&\& make install

d. Edit file konfigurasi squid di /etc/squid.conf untuk mengaktifkan modul Tproxy pada squid http_port 3129 tproxy

e. Edit rule pada IP tables untuk me-redirect port $80 \mathrm{ke} \mathrm{port} \mathrm{Tproxy} \mathrm{pad/root/frw1.sh}$ \#!/bin/bash 
iptables -t mangle -A PREROUTING -p tcp --dport 80 -j TPROXY --tproxy-mark 0x1/0x1 -on-port 3129

f. Edit rule Eb tables untuk interface bridge pada/root/frw2.sh

\#!/bin/bash

ebtables -t broute -A BROUTING -i eth1 -p ipv4 --ip-proto tcp --ip-dport 80 -j redirect -redirect-target ACCEPT

ebtables -t broute -A BROUTING -i eth0 -p ipv4 --ip-proto tcp --ip-sport 80 -j redirect -redirect-target ACCEPT

$\mathrm{cd} / \mathrm{proc} / \mathrm{sys} / \mathrm{net} / \mathrm{bridge} /$

for $\mathrm{i}$ in *

do

echo $0>\$ \mathrm{i}$

done

unset $\mathrm{i}$

g. Edit file /etc/rc.local untuk menjalankan modul Tproxy setiap kali restart server
/sbin/modprobe xt_TPROXY
/usr/sbin/squid
ip rule add fwmark 1 lookup 100
ip route add local $0.0 .0 .0 / 0$ dev lo table 100
/root/frw1.sh
/root/frw2.sh
/sbin/route add -net 186.194.x.0/24 gw 186.193.x.2
exit 0

\subsection{Pengaturan Filtering pada Router OS}

a. Menentukan dan memasukkan pattern dari suatu regexp paket data atau protocol. Contoh untuk layer 7 bittorent

/ip firewall layer7-protocol add comment="" name=bittorrent regexp="^(||x13bittorrent protocol|azver||x01 $\$||$ get/scrapell| ?info_hash=|get/announcel|l?info_hash=|get/client/bitcom etV|GET/datallI?fid=)|d1:ad2:id20:||Xx08'7PII)[RP]"

Contoh untuk layer 7 protokol Telnet

/ip firewall layer7-protocol add comment="" name=telnet regexp=|"^||xff[|xfb||xfe].||xff[|xfb\|xfe].\|xff[\|xfb-\|xfe]" layer-7

Pengetahuan Regexp (Regular Expression) sangat dibutuhkan dalam pemanfaatan

b. Pengaturan Filtering / firewall

Jika paket data dizinkan maka pengaturan pada firewall adalah sebagai berikut:

/ip firewall filter

add action=accept chain=input comment="' disabled=no layer7-protocol=telnet protocol=tcp 
add action=passthrough chain=output comment="' disabled=no layer7-protocol=telnet protocol=tcp

Jika paket data tidak diizinkan maka parameter action adalah DROP atau REJECT

\section{KESIMPULAN}

Sebuah teknologi proxy yang terkenal adalah Squid, tetapi belum banyak tenaga IT yang memahami bagaimana mengoptimalkan Squid menjadi sebuah proxy server yang benar-benar mempunyai kemampuan memberikan nilai efisiensi terhadap konsumsi bandwidth yang baik. Dengan teknologi TProxy yang dipadukan dengan Kernel Linux terbaru dapat dibangun sebuah perangkat proxy server yang optimal. Pada akhirnya setiap permintaan atau query dari klien atau respon dari proxy server tidak mempunyai hambatan berarti, bandwidth antara klien dengan proxy server tidak terjadi limitasi, bandwidth yang berjalan mampu mendekati kemampuan ethernet diantaranya $10 \mathrm{Mbps}, 100 \mathrm{Mbps}$, bahkan $1 \mathrm{Gps}$ (full speed).

Kemampuan tenaga IT dalam memahami Regular Expression sangat bermanfaat dalam hal filtering paket data dan protokol. Hal ini mampu meminimalisasi trafik-trafik data sampah atau data yang tidak diinginkan, yang pada akhirnya juga membantu optimasi penggunaan bandwidth internet. 


\section{PUSTAKA}

10.04.http://www.linuxinfo.com.br/squid_tproxy_ubuntu.htm

Mikrotik Documentations, Bandwidth Management, http://www.mikrotik.com

Mikrotik Wiki, Filtering Layer 7 Protocol, http://wiki.mikrotik.com/wiki/L7

Princefafa. Mengatur Bandwidth Linux,.http://itclinic.unitomo.ac.id/?p=55

Ropix, 2006, Mikrotik OS Untuk Bandwidth Manajemen, http://www.ilmukomputer.com

Santoso, Budi, 2007, Manajemen Bandwidth Internet dan Intranet, http://budisantoso.com

Tajidyakub, Squid Cache, Tproxy, Mikrotik, Alternatif Untuk Perpaduan Jaringan Sederhana,http://www.tajidyakub.net/2007/08/08/squid-cache-tproxy-dan-mikrotik-alternatifperpaduan-untuk-jaringan-sederhana/

Trimantaraningsih, R., Muarifah, I. 2008,Prosiding Seminar Nasional Aplikasi Saint dan Teknologi, Implementasi Mikrotik Sebagai Manajemen Bandwidth, p.283

Wikipedia, Lebar Pita atau Bandwidth, http://id.wikipedia.org/wiki/Bandwidth . Squid Transparent Proxy, http://www.squid-cache.com 